\title{
Deoxyribonucleic Acid Relatedness Between Enterobacter cloacae and Enterobacter amnigenus sp. nov.
}

\author{
D. IZARD, F. GAVINI, P. A. TRINEL, AND H. LECLERC \\ Institut Pasteur de Lille, Unité INSERM 146, Université de Lille II, Domaine du C.E.R.T.I.A., 59651 \\ Villeneuve d'Ascq Cedex, France
}

\begin{abstract}
A deoxyribonucleic acid (DNA)-DNA hybridization study was carried out to determine the taxonomic position of a new group of enterobacters (group $\mathrm{H}_{3}$, Gavini et al. [Ann. Microbiol. (Inst. Pasteur) 127B:317-335, 1976]) previously studied by numerical taxonomy. The reassociation binding ratios with the group $\mathrm{H}_{3}$ strain ATCC 33072 ranged from 61 to $97 \%$. With respect to DNA hybridization, this group, which represents a new species in the genus Enterobacter, Enterobacter amnigenus, is closely related (49 to $66 \%)$ to Enterobacter cloacae. A difference in genome size between $E$. amnigenus ATCC 33072 and $E$. cloacae Collection de l'Unité d'Écotoxicologie Microbienne (CUETM) 77-120 was observed after reciprocal binding: the genome of ATCC 33072 was $24 \%$ larger. $E$. amnigenus was defined from phenotypic and genetic data. The type strain of $E$. amnigenus is CUETM 77-118 (ATCC 33072).
\end{abstract}

In a previous numerical taxonomy study of the genus Enterobacter, Gavini et al. (11) showed clearly the existence of three new groups $\left(\mathrm{H}_{1}, \mathrm{H}_{2}\right.$, and $\left.\mathrm{H}_{3}\right)$ phenotypically related to $E n$ terobacter cloacae. The purpose of this study is to define the taxonomic position of group $\mathrm{H}_{3}$ by deoxyribonucleic acid (DNA)-DNA hybridization.

\section{MATERIALS AND METHODS}

Bacterial strains. The strains used in this study were previously listed in detail $(9,16)$. All of the Collection de l'Unité d'Écotoxicologie Microbienne (CUETM) strains have been studied by Gavini et al. (10-13) with a numerical taxonomy procedure.

Methods. DNA extraction was performed by Marmur's method (20) as slightly modified by Ferragut and Leclerc (8). The purity and quality of each DNA preparation was checked by determination of the absorbancy ratio at $260 \mathrm{~nm} / 280 \mathrm{~nm}(1.8$ to 1.9$)$ and 260 $\mathrm{nm} / 230 \mathrm{~nm}$ (2 to 2.3) as described by Marmur (20) and by determination of melting point $\left(T_{m}\right)$ curves, which include hyperchromicity values from 30 to $40 \%$ (19).

The strains chosen for DNA labeling were the centrostrain (the strain most phenotypically similar to the others in a taxon) of group $\mathrm{H}_{3}$, CUETM $77-118$ (Gravini et_al. [11]), and the centrostrain of group G (Enterobacter cloacae; Gavini et al. [11]), CUETM 77-120. For the preparation of labeled DNA, $1 \mathrm{mCi}$ of $\left[{ }^{3} \mathrm{H}\right]$ thymidine (specific activity, 10 to $25 \mathrm{Ci} / \mathrm{mmol}$ ) was added to $500 \mathrm{ml}$ of a synthetic medium containing $4 \mathrm{~g}$ of glucose, $4 \mathrm{~g}$ of Casamino Acids, and $250 \mu \mathrm{g}$ of deoxyadenosine per liter to inhibit the activity of thymidylate synthetase. The cells were harvested in the late-log phase. The specific activity was 80,000 $\mathrm{cpm} / \mu \mathrm{g}$ for ${ }^{3} \mathrm{H}$-labeled DNA. The unlabeled DNA of high molecular weight was denatured and fixed on nitrocellulose filters by the technique described by De Ley and Tijtgat (6). Fragmentation of unlabeled and labeled DNA was carried out in a French pressure cell at a pressure of $20,000 \mathrm{lb} / \mathrm{in}^{2}$. DNA reassociation was done by competition reaction under the conditions employed by De Ley and Tijtgat and described by Legault-Demare et al. (18). The optimal temperature of renaturation $\left(T_{\mathrm{OR}, \mathrm{D}}\right.$ ) was calculated from the equation of De Ley and Tijtgat: $T_{\mathrm{OR}, \mathrm{D}}=0.51 \mathrm{~mol} \%$ of guanine plus cytosine +28.0 . The guanine plus cytosine content of labeled DNAs equaled $54.3 \mathrm{~mol} \%$ for strain CUETM 77-118 (15) and $55.7 \mathrm{~mol} \%$ for strain CUETM 77-120 (15). Consequently, the optimal temperatures of incubation were 55.7 and $56.4^{\circ} \mathrm{C}$, respectively. The time of incubation was $16 \mathrm{~h}$. Radioactivity counting was done by scintillation counting, using 10 $\mathrm{ml}$ of Bray's solution (1) in vials.

The rate of reassociation was calculated by the formula: counts per minute without competitor DNA - counts per minute with heterologous DNA/counts per minute without competitor DNA - counts per minute with homologous DNA $\times 100$.

\section{RESULTS}

The phenotype data of Gavini et al. (11) on the group $\mathrm{H}_{3}$ strains are summarized in Table 1.

The reassociation data obtained with labeled DNA of group $\mathrm{H}_{3}$ strain CUETM 77-118 are presented in Table 2. The DNA relatedness of strain CUETM 77-118 to 18 other isolates of the same group ranged from 97 to $61 \%$. The reference strain of group $\mathrm{H}_{3}$ shared 49 to $66 \%$ of its genome with $E$. cloacae and 52 to $65 \%$ with the strains of group $\mathrm{E}$ ( $E$. cloacae acetoin-negative strains; Gavini et al. [13]). These ranges of relative binding ratios with $E$. cloacae (acetoin-positive or -negative strains) showed a genetic relationship between group $\mathrm{H}_{3}$ and the genus $E n$ terobacter. Strain $77-118$ exhibited 46 to $54 \%$ relatedness with the genus Levinea and 46 to 
TABLE 1. Phenotype characterization of group $\mathrm{H}_{3}$ strains ${ }^{a}$

\begin{tabular}{|c|c|c|c|}
\hline \multirow{2}{*}{ Characteristic } & \multicolumn{2}{|c|}{ Group $\mathrm{H}_{3}(N=28)^{b}$} & \multirow{2}{*}{$\begin{array}{c}\text { Strain } \\
\text { CUETM } \\
77.118 \\
\text { (ATCC } 33072 \text { ) } \\
\text { reaction }\end{array}$} \\
\hline & Reaction ${ }^{c}$ & $+(+)$ Strains $(\%)$ & \\
\hline \multicolumn{4}{|l|}{ Growth at temp $\left({ }^{\circ} \mathrm{C}\right)$ : } \\
\hline 4 & $t_{4}$ & 96 & $+_{4}$ \\
\hline 41 & - & 0 & - \\
\hline 44.5 & - & 0 & - \\
\hline \multicolumn{4}{|l|}{ Motility at temp $\left({ }^{\circ} \mathrm{C}\right)$ : } \\
\hline 30 & + & 100 & + \\
\hline 37 & + or - & 89.3 & + \\
\hline $\mathrm{KCN}$ & + or - & 53 & - \\
\hline Lysine decarboxylase & - & 0 & - \\
\hline Arginine dihydrolase & + & 96 & + \\
\hline Ornithine decarboxylase & + & 100 & + \\
\hline Gelatin liquefaction $\left(20^{\circ} \mathrm{C}\right)$ & - & 0 & - \\
\hline Urease & + or - & 50 & $+_{4}$ \\
\hline Indole & - & 0 & - \\
\hline Methyl red test $\left(30^{\circ} \mathrm{C}\right)$ & - & 0 & - \\
\hline Methyl red test $\left(37^{\circ} \mathrm{C}\right)$ & - & 0 & - \\
\hline Voges-Proskauer reaction $\left(30^{\circ} \mathrm{C}\right)$ & + & 100 & + \\
\hline Voges-Proskauer reaction $\left(37^{\circ} \mathrm{C}\right)$ & + or - & 89.3 & + \\
\hline Citrate (Simmons) $\left(30^{\circ} \mathrm{C}\right)$ & + & 100 & + \\
\hline Citrate (Simmons) $\left(37^{\circ} \mathrm{C}\right)$ & + & 100 & + \\
\hline Malonate & + & 100 & + \\
\hline D-Tartrate ${ }^{d}$ & - & 0 & - \\
\hline L-Tartrate ${ }^{d}$ & - & 0 & - \\
\hline$m$-Tartrate ${ }^{d}$ & - & 0 & - \\
\hline Mucate $^{d}$ & + & 100 & + \\
\hline Jordan tartrate & - & 0 & - \\
\hline Phenylalanine deaminase & - & 0 & - \\
\hline Nitrate to nitrite & + & 100 & + \\
\hline $\mathrm{H}_{2} \mathrm{~S}$ production & - & 0 & - \\
\hline Tetrathionate reductase & - & $\mathbf{0}$ & - \\
\hline Tween esterase & - & 0 & - \\
\hline Deoxyribonuclease & - & 0 & - \\
\hline Chitinolysis & - & 0 & - \\
\hline$\beta$-Galactosidase & + & 100 & + \\
\hline$\beta$-Xylosidase & + & 100 & + \\
\hline \multicolumn{4}{|l|}{ Fermentation of: } \\
\hline L-Arabinose & + & 100 & + \\
\hline D-Xylose & + & 96 & + \\
\hline D-Ribose & + & 100 & + \\
\hline Maltose & + & 100 & + \\
\hline D-Glucose (gas) & + & 100 & + \\
\hline D-Lactose & $(+)$ or + & $21(78.6)$ & $t_{5}$ \\
\hline D-Galactose & + & 100 & + \\
\hline L-Rhamnose & + & 96 & + \\
\hline D-Mannose & + & 100 & + \\
\hline D-Fructose & + & 100 & + \\
\hline$\alpha$-Methyl D-glucoside & $(+)$ or + & 35 & $+_{4}$ \\
\hline D-Trehalose & + & 100 & + \\
\hline Raffinose & + & 96 & + \\
\hline L-Sorbose & - & 0 & - \\
\hline Melibiose & + & 100 & + \\
\hline D-Melezitose & - & 0 & - \\
\hline D-Sucrose & + or - & 64 & + \\
\hline D-Mannitol & + & 100 & + \\
\hline D-Dulcitol & - & 3 & - \\
\hline meso-Inositol & - & 0 & - \\
\hline
\end{tabular}




\begin{tabular}{|c|c|c|c|}
\hline \multirow{2}{*}{ Characteristic } & \multicolumn{2}{|c|}{ Group $\mathrm{H}_{3}(N=28)^{b}$} & \multirow{2}{*}{$\begin{array}{l}\text { Strain } \\
\text { CUETM } \\
77.118 \\
\text { (ATCC } 33072) \\
\text { reaction }\end{array}$} \\
\hline & Reaction $^{c}$ & $+(+)$ Strains $(\%)$ & \\
\hline D-Cellobiose (acid) & + & 100 & + \\
\hline D-Cellobiose (gas) & + & 100 & + \\
\hline D-Glycerol (gas) & - & 0 & - \\
\hline D-Sorbitol & - or + & 46 & - \\
\hline Adonitol & - & 0 & - \\
\hline meso-Erythritol & - & 0 & - \\
\hline Salicin & + or - & 89 & + \\
\hline Inulin & - & 0 & - \\
\hline Glycogen & - or + & 28 & - \\
\hline Esculin hydrolysis & + & 100 & + \\
\hline \multicolumn{4}{|c|}{$\begin{array}{l}{ }^{a} \text { Gavini et al. (11) and unpublished data. } \\
{ }^{b} N \text {, Number of strains tested. } \\
{ }^{c} \text { Numbers after symbols indicate number of days needed for reaction to take place. }+ \text {, Positive reaction fo } \\
t \text { least } 90 \% \text { of the strains within } 24 \text { to } 48 \mathrm{~h} ;(+) \text {, slow positive reaction (i.e., } 2 \text { to } 30 \text { days); }- \text {, negative reactior } \\
\text { r at least } 90 \% \text { of the strains. } \\
{ }^{d} \text { Kauffmann's method. }\end{array}$} \\
\hline
\end{tabular}

$51 \%$ relatedness with group L of Gavini et al. (12), which is phenotypically related to the genus Klebsiella.

The DNA relatedness values between the reference strain of group $\mathrm{H}_{3}$ and the cultures belonging to the different species of Enterobacteriaceae and to the new groups of Gavini et al. (groups D and F related to the genus Citrobacter $[7,9,13]$; groups $\mathrm{H}_{1}$ and $\mathrm{H}_{2}$ related to the genus Enterobacter [11, 15-17]; and groups K and L related to the genus Klebsiella [12]) are also listed in Table 2. The results are given in descending order for each species or group. For all of these taxa (except $E$. cloacae, the genus Levinea, and group L) the relatedness results were in the range of 8 to $46 \%$.

The reassociation data obtained with labeled DNA of E. cloacae CUETM 77-120 are given in Table 3. E. cloacae CUETM 77-120 was selected as the donor of radioactively labeled DNA, for it is the centrostrain of group $\mathrm{G}$ ( $E$. cloacae; Gavini et al. [11]). As previously shown by Steigerwalt et al. (22), strains of $E$. cloacae show only 62 to $97 \%$ interrelatedness. Our study confirmed the existence of a distinct group of acetoin-negative strains of $E$. cloacae (group $\mathrm{E}$ of Gavini et al. [13]).

We next tested the relatedness of $E$. cloacae and group $\mathrm{H}_{3}$. Reciprocal binding values between strains CUETM 77-118 and CUETM 77120 were used to approximate their relative genome size. These results showed that the values obtained in the two series of reactions were not identical (60 and 46\%). The genome of $E$. cloacae CUETM 77-120 was $24 \%$ larger than that of CUETM 77-118. Such differences in genome size in the family Enterobacteriaceae have been mentioned previously by different authors (Brenner et al. [2, 3]; Gillis et al. [14]; Crosa et al. $[4,5]$; and Steigerwalt et al. [22]).

\section{DISCUSSION}

The DNA-DNA hybridization results obtained in this study correlate well with the results obtained for the same strains by numerical taxonomy (11). Both types of data confirm that $E$. cloacae and group $\mathrm{H}_{3}$, although closely related, are distinct both phenotypically and genetically (Fig. 1). The characteristics used in differentiating $E$. cloacae from group $\mathrm{H}_{3}$ are listed in Table 4. We therefore treat group $\mathrm{H}_{3}$ as a new species, Enterobacter amnigenus (L. adj: amnigenus: coming from water), because all of the strains of this taxon have been isolated from well waters and springs.

E. amnigenus sp. nov. The following description of $E$. amnigenus is based on the data obtained by Gavini et al. (11) and Izard et al. (15) from studies of 28 strains.

Gram-negative, peritrichous, nonsporeforming, straight rods $(0.5$ by $30 \mu \mathrm{m})$ resembling those of the other members of Enterobacteriaceae. Never encapsulated. Growth on nutrient agar occurs at 30 and $37^{\circ} \mathrm{C}$ but not at $41^{\circ} \mathrm{C}$.

The following biochemical reactions are positive: acetoin production, citrate (Simmons), mucate and malonate utilization, reduction of nitrates to nitrites, ornithine decarboxylase and arginine dihydrolase production, production of $\beta$-galactosidase and $\beta$-xylosidase, and fermentation of the following carbohydrates within 24 to $48 \mathrm{~h}$ (for 80 to $100 \%$ of the strains): glucose (with gas production), arabinose, xylose, ribose, mal- 
TABLE 2. Relative reassociation of labeled DNA from strain CUETM 77-118 (centrostrain of $\mathrm{H}_{3}, 28$ strains) with DNA from members of the family Enterobacteriaceae ${ }^{a}$

\begin{tabular}{|c|c|c|c|}
\hline Source of unlabeled DNA & $\begin{array}{c}\text { Relative } \\
\text { binding } \\
\text { at } T_{\mathrm{OR}, \mathrm{D}} \\
\left(55.7^{\circ} \mathrm{C}\right) \\
(\%)\end{array}$ & Source of unlabeled DNA & $\begin{array}{c}\text { Relative } \\
\text { binding } \\
\text { at } T_{\mathrm{OR}, \mathrm{D}} \\
\left(55.7^{\circ} \mathrm{C}\right) \\
(\%)\end{array}$ \\
\hline Group $\mathrm{H}_{3}$ & & ATCC 6750 & 36 \\
\hline CUETM 77-118 & 100 & ATCC 8090 & 32 \\
\hline CUETM 78-65 & 97 & & \\
\hline CUETM 78-78 & 96 & "Salmonella houtenae" CRR 498 & 40 \\
\hline CUETM 78-83 & 96 & Salmonella arizonae CDC 62 & 31 \\
\hline CUETM 78-97 & 94 & Salmonella typhimurium LT 2 & 28 \\
\hline CUETM 78-73 & 89 & Shigella sonnei WRAIR Virulent & 37 \\
\hline CUETM 77-137 & 88 & Shigella flexneri ATCC 12661 & 36 \\
\hline CUETM 78-96 & 86 & Shigella dysenteriae WRAIR A1 & 30 \\
\hline CUETM 78-86 & 74 & Escherichia coli ATCC 10536 & 35 \\
\hline CUETM 78-77 & 71 & & \\
\hline CUETM 78-70 & 70 & Group F & \\
\hline CUETM 78-75 & 70 & CUETM 78-135 & 35 \\
\hline CUETM 78-89 & 70 & CUETM 78-3 & 30 \\
\hline CUETM 78-98 & 67 & & \\
\hline CUETM 78-79 & 64 & Enterobacter aerogenes & \\
\hline CUETM 78-100 & 64 & ATCC 13048 & 34 \\
\hline CUETM 77-132 & 64 & CUETM 78-160 & 33 \\
\hline CUETM 78-81 & 62 & & \\
\hline CUETM 78-74 & 61 & Group E & \\
\hline & & CUETM 77-160 & 65 \\
\hline E. cloacae & & CUETM 78े-37 & 62 \\
\hline CUETM & & CUETM 78-2 & 59 \\
\hline $77-125$ & 66 & CUETM 78-1 & 59 \\
\hline $77-116$ & 62 & CUETM 78-42 & 58 \\
\hline $77-41$ & 61 & CUETM 77-158 & 54 \\
\hline $77-120$ & 60 & CUETM 77-15d & 52 \\
\hline $77-135$ & 60 & & \\
\hline ATCC 13047 & 58 & Levinea amalonatica & \\
\hline CUETM & & R $17996 / 73$ & 54 \\
\hline $77-126$ & 57 & CUETM 78-327 & 54 \\
\hline $77-138$ & 54 & CDC 25406 & 52 \\
\hline $77-121$ & 53 & & \\
\hline \multirow[t]{2}{*}{$77-119$} & 49 & Levinea malonatica & \\
\hline & & CDC 25408 & 50 \\
\hline Klebsiella pneumoniae & & LM 2-70 & 46 \\
\hline CUETM & & R 16 & 44 \\
\hline $77-169$ & 42 & & \\
\hline $77-170$ & 41 & Citrobacter diversus CDC 3613-63 & 46 \\
\hline $77-180$ & 39 & & \\
\hline $77-174$ & 39 & Group L & \\
\hline LM 47-70 & 37 & CUETM 77-177 & 51 \\
\hline CUETM 77-181 & 35 & CUETM 77-146 & 46 \\
\hline Group $\mathrm{H}_{1}$ & & Group D & \\
\hline CUETM 77-130 & 42 & CUETM 78-325 & 46 \\
\hline CUETM 77-147 & 36 & CUETM 78-324 & 40 \\
\hline CUETM 77-145 & 32 & CUETM 78-13 & 35 \\
\hline CUETM 77-148 & 30 & CUETM 78-30 & 30 \\
\hline CUETM 77-139 & 29 & & \\
\hline CUETM $77-123$ & 26 & Klebsiella oxytoca & \\
\hline CUETM 77-140 & 26 & LM 25-70 & 44 \\
\hline CUETM 77-124 & 25 & CUETM 78-323 & 44 \\
\hline \multirow[t]{2}{*}{ CUETM $78-87$} & 25 & & \\
\hline & & Klebsiella ozaenae CDC 276-71 & 34 \\
\hline Citrobacter freundii & & Serratia rubidaea CDC 2199-72 & 32 \\
\hline CUETM 77-166 & 41 & Serratia marcescens CDC 868-57 & 31 \\
\hline CDC 2987-57 & 39 & Serratia marcescens ATCC 13880 & 25 \\
\hline
\end{tabular}


TABLE 2.-Continued

\begin{tabular}{|c|c|c|c|}
\hline Source of unlabeled DNA & $\begin{array}{c}\text { Relative } \\
\text { binding } \\
\text { at ToR,D } \\
\left(55.7^{\circ} \mathrm{C}\right) \\
(\%)\end{array}$ & Source of unlabeled DNA & $\begin{array}{c}\text { Relative } \\
\text { binding } \\
\text { at Tor,D } \\
\left(55.7^{\circ} \mathrm{C}\right) \\
(\%)\end{array}$ \\
\hline Serratia liquefaciens LM 3-70 & 29 & CUETM 77-108 & 20 \\
\hline Serratia fonticola ATCC 29848 & 29 & CUETM 77-115 & 11 \\
\hline Serratia fonticola ATCC 29844 & 27 & CUETM 77-146 & 7 \\
\hline Serratia plymuthica B 36-17 & 27 & & \\
\hline \multicolumn{4}{|l|}{ Enterobacter agglomerans } \\
\hline R 6 & 27 & Edwardsiella tarda CUETM 77-185 & 21 \\
\hline \multirow[t]{2}{*}{ ATCC 27155} & 16 & Proteus mirabilis ATCC 9240 & 19 \\
\hline & & Hafnia alvei CUETM 78-268 & 15 \\
\hline "Rahnella aquatilis" (group $\mathrm{H}_{2}$ ) & & Yersinia enterocolitica CUETM 77-75 & 10 \\
\hline CUETM 78-68 & 27 & Yersinia pseudotuberculosis LM 48-1 & 8 \\
\hline
\end{tabular}

${ }^{a}$ Names in quotation marks are not on the Approved Lists of Bacterial Names (21). ATCC, American Type Culture Collection, Rockville, Md.; B, P. Brisou, University of Poitiers, Poitiers, France; CDC, Centers for Disease Control, Atlanta, Ga.; CRR, Center for Reference and Research on Salmonella (L. Le Minor, Institut Pasteur de Paris, Paris, France); CUETM, Collection de l'Unité d'Ecotoxicologie Microbienne, 59651 Villeneuve d'Ascq, France; LM, L. Le Minor, Institut Pasteur de Paris, Paris, France; R, C. Richard, Institut Pasteur de Paris, Paris, France; WRAlR, Walter Reed Army Institute of Research, Washington, D.C.; $T_{\mathrm{OR}, \mathrm{D}}$, temperature of optimal renaturation.

TABLE 3. Relative reassociation of labeled DNA from E. cloacae CUETM 77-120 with DNA from groups E and $\mathrm{H}_{3}$

\begin{tabular}{|c|c|c|c|}
\hline $\begin{array}{c}\text { Source of } \\
\text { unlabeled DNA }\end{array}$ & $\begin{array}{c}\text { Relative } \\
\text { binding } \\
\text { at } T_{\text {OR, }}{ }^{a} \\
\left(56.4^{\circ} \mathrm{C}\right) \\
(\%)\end{array}$ & $\begin{array}{c}\text { Source of } \\
\text { unlabeled DNA }\end{array}$ & $\begin{array}{c}\text { Relative } \\
\text { binding } \\
\text { at } T_{\text {or,o }}{ }^{a} \\
\left(56.4^{\circ} \mathrm{C}\right) \\
(\%)\end{array}$ \\
\hline $\begin{array}{c}\text { E. cloacae } \\
\text { CUETM } \\
77-120 \\
77-121 \\
77-126 \\
77-116 \\
77-41 \\
77-134 \\
77-135 \\
77-138 \\
\text { ATCC 13047 } \\
\text { CDC 1347-71 } \\
\text { CUETM 77-119 } \\
\\
\text { Group E } \\
\text { CUETM 78-2 } \\
\text { CUETM 78-1 } \\
\text { CUETM 77-160 } \\
\text { CUETM 77-158 } \\
\text { CUETM 77-137 } \\
\text { CUETM 77-150 } \\
\text { CUETM 78-42 }\end{array}$ & $\begin{array}{r}100 \\
97 \\
91 \\
86 \\
86 \\
74 \\
73 \\
70 \\
69 \\
66 \\
62\end{array}$ & $\begin{array}{l}{\text { Group } \mathrm{H}_{3}} \\
\text { CUETM } 78-75 \\
\text { CUETM } 78-70 \\
\text { CUETM } 78-100 \\
\text { CUETM } 77-132 \\
\text { CUETM } 78-74 \\
\text { CUETM } 78-98 \\
\text { CUETM } 78-89 \\
\text { CUETM } 77-137 \\
\text { CUETM } 78-77 \\
\text { CUETM } 78-79 \\
\text { CUETM } 78-73 \\
\text { CUETM } 78-96 \\
\text { CUETM } 78-81 \\
\text { CUETM 77-118 } \\
\text { CUETM } 78-78 \\
\text { CUETM } 78-83 \\
\text { CUETM 78-65 } \\
\text { CUETM 78-86 } \\
\text { CUETM } 78-97\end{array}$ & $\begin{array}{l}56 \\
55 \\
54 \\
53 \\
53 \\
52 \\
52 \\
52 \\
50 \\
48 \\
48 \\
47 \\
46 \\
46 \\
44 \\
44 \\
42 \\
42 \\
40\end{array}$ \\
\hline
\end{tabular}

${ }^{a} T_{\text {OR.D, }}$ Temperature of optimal renaturation.

tose, galactose, rhamnose, mannose, fructose, raffinose, melibiose, cellobiose, mannitol, salicin, and esculin. The following reactions are negative: indole production, methyl red test, tartrate utilization (Jordan), $\mathrm{H}_{2} \mathrm{~S}$ production, phenylal- anine deaminase production, lysine decarboxylase, gelatinase, Tween esterase, tetrathionate reductase, deoxyribonuclease, and fermentation of the following carbohydrates within 30 days (for 80 to $100 \%$ of the strains): lactose, sorbose, 
RBR with E. cloacae CUETM 77-120

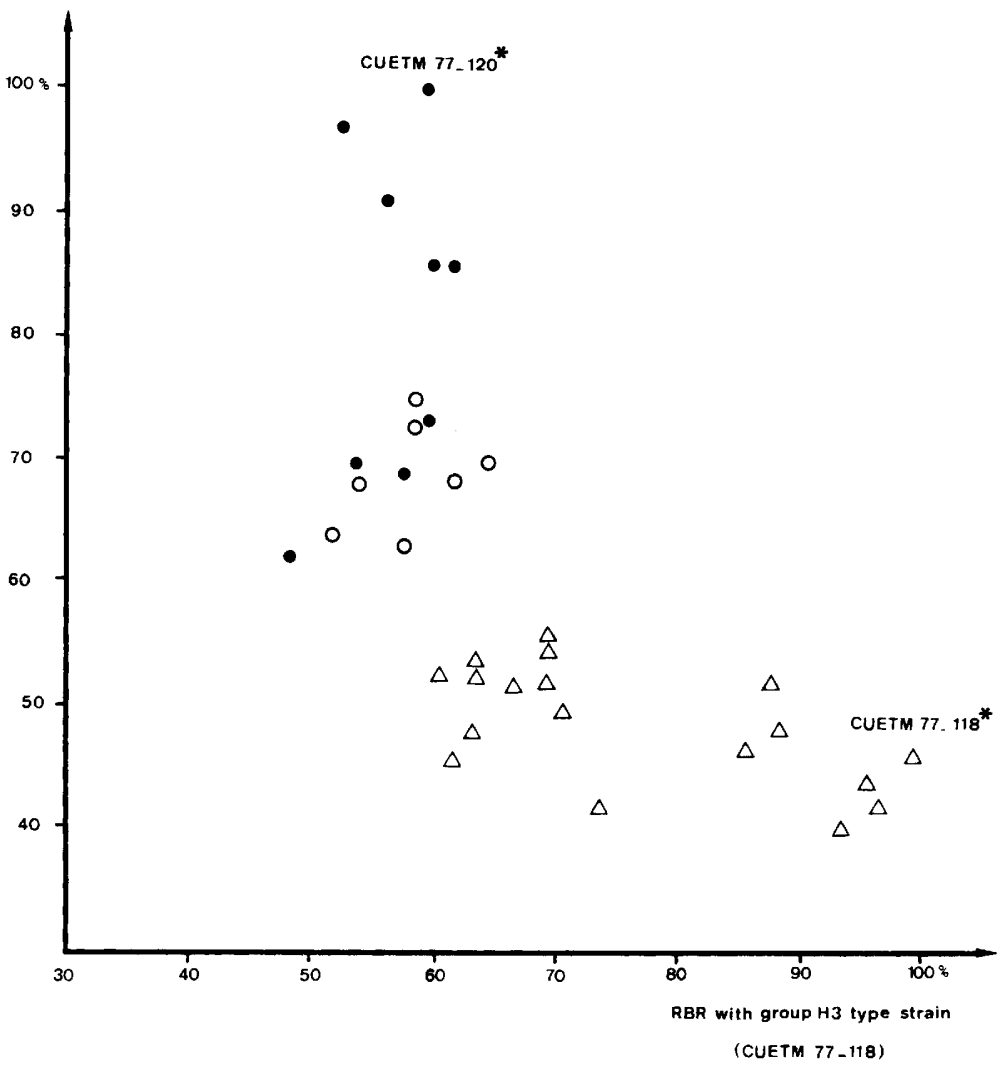

FIG. 1. Genetic relationships between $E$. cloacae and group $H_{3}$. $R B R$, Relative binding ratio; $\bullet$, E. cloacae acetoin-positive group $G ; O, E$. cloacae acetoin-negative group $E ; \triangle$, group $H_{3} ;{ }^{*}$, labeled DNA.

TABLE 4. Characteristics useful in differentiating E. cloacae from E. amnigenus (group $\mathrm{H}_{3}$ )

\begin{tabular}{|c|c|c|c|c|}
\hline \multirow{2}{*}{ Characteristics } & \multicolumn{2}{|c|}{ E. cloacae } & \multicolumn{2}{|c|}{ E. amnigenus $(N=28)^{a}$} \\
\hline & Reaction $^{b}$ & $+(+)$ Strains $(\%)$ & Reaction $^{b}$ & + Strains $(\%)$ \\
\hline \multicolumn{5}{|l|}{ Growth at temp $\left({ }^{\circ} \mathrm{C}\right)$ : } \\
\hline 4 & d & 9.5 & + & 100 \\
\hline 41 & + & 100 & - & 0 \\
\hline Gelatin liquefaction at $20^{\circ} \mathrm{C}$ & $(+)$ & (98.4) & - & 0 \\
\hline \multicolumn{5}{|l|}{ Fermentation } \\
\hline Sorbitol & + & 96.8 & - or + & 46 \\
\hline Esculin & - or + & 31.7 & + & 100 \\
\hline Salicin & $(+)$ or + & $39.7(57.1)$ & + or - & 89 \\
\hline \multicolumn{5}{|l|}{ Carbon source utilization } \\
\hline Aconitate & + & 92.1 & - & 0 \\
\hline Phenyl acetate & + or - & 81 & - & 0 \\
\hline Asparagine & + or - & 73 & - & 0 \\
\hline L-Serine & + & 90.9 & - or + & 32.1 \\
\hline
\end{tabular}

\footnotetext{
${ }^{a} N$, Number of strains tested.
}

${ }^{b}$ Symbols: + , positive reaction for at least $90 \%$ of the strains within 24 to $48 \mathrm{~h} ;(+)$, slow positive reaction (i.e., between 2 and 30 days for fermentation reactions); + or,-- or + , the first sign corresponds to the more frequent result; -, negative reaction for at least $90 \%$ of the strains; $d$, different biochemical types $[+,(+),-]$. 
melezitose, dulcitol, inositol, glycerol, adonitol, erythritol, inulin, dextrin, starch, pectin, and chitin.

The following are utilized (by 80 to $100 \%$ of the strains) as sole carbon sources: $D$-fructose, $D$ galactose, D-glucose, D-mannose, D-maltose, Dtrehalose, D-cellobiose, D-ribose, D-xylose, L-arabinose, L-rhamnose, starch, salicin, gluconate, D-mannitol, DL-glycerate, citrate, fumarate, DLlactate, L-malate, pyruvate, L- $\alpha$-alanine, D- $\alpha$-alanine, and L-glutamate. The following are not utilized (by 80 to $100 \%$ of the strains within 5 days) as sole carbon sources: D-fucose, inulin, ethanol, methanol, $n$-propanol, iso-propanol, geraniol, 2,3-butylene glycol, ethylene glycol, propylene glycol, erythritol, adonitol, D-dulcitol, meso-inositol, propionate, D-tartrate, L-tartrate, meso-tartrate, levulinate, citraconate, itaconate, mesaconate, glycolate, aconitate, D-malate, 2 -ketoglutarate, oxalate, acetate, DL-3-hydroxybutyrate, maleate, pimelate, suberate, azelate, glutarate, sebacate, salicylate, butyrate, iso-butyrate, $n$-valerate, iso-valerate, $n$-caproate, heptanoate, adipate, caprate, pelargonate, caprylate, phenol, phthalate, iso-phthalate, tere-phthalate, benzylformate, $\mathrm{D}$ - and L-mandelate, $p$-hydroxybenzoate, phenyl acetate, benzoate, $m$-hydroxybenzoate, $\mathrm{D}$-quinate, glycine, $\beta$-alanine, L-leucine, L-isoleucine, L-valine, L-lysine, L-citrulline, L-methionine, DL-2-aminobutyrate, DL-3-aminobutyrate, $\mathrm{DL}$-4-aminobutyrate, L-aspartate, L-arginine, L-ornithine, L-threonine, L-cysteine, 5aminovalerate, L-phenylalanine, L-tyrosine, 2aminobenzoate, 3-aminobenzoate, 4-aminobenzoate, L-tryptophan, histamine, putrescine, spermine, tryptamine, amylamine, ethanolamine, butylamine, benzylamine, diphenylamine, urea, urate, sarcosine, betaine, creatine, hippurate, pantothenate, nicotinate, trigonelline, asparagine, acetamide, potassium nitrate, naphthalene, dodecane, and hexadecane.

Mean guanine plus cytosine content of DNA: $54.2 \mathrm{~mol} \%$ (5 strains analyzed [15]).

Genetic relatedness (DNA-DNA hybridization) with the most related species or genus: $E$. cloacae (49-66\%; 17 strains analyzed); Levinea (46-54\%; 7 strains analyzed).

Found in water (drinking water and surface water) and unpolluted soils.

Type strain: CUETM 77-118 (ATCC 33072).

\section{ACKNOWLEDGMENTS}

We thank J. De Ley and M. Véron for their constructive comments and continued interest in our work. We also thank E. Dewailly and A. Bernigaud for their technical assistance.

\section{REPRINT REQUESTS}

Address reprint requests to: Daniel Izard, Unité INSERM 146, Domaine du C.E.R.T.I.A., B.P. 39, 59651 Villeneuve d'Ascq Cedex, France.

\section{LTERATURE CITED}

1. Bray, G. A. 1960. A simple efficient liquid scintillator for counting aqueous solutions in a liquid scintillation counter. Anal. Biochem. 1:279-285.

2. Brenner, D. J., G. R. Fanning, F. J. Skerman, and S. Falkow. 1972. Polynucleotide sequence divergence among strains of Escherichia coli and closely related organisms. J. Bacteriol. 109:953-965.

3. Brenner, D. J., G. R. Fanning, and A. G. Steigerwalt. 1977. Deoxyribonucleic acid relatedness among erwiniae and other enterobacteria. II. Corn stalk rot bacterium and Pectobacterium chrysanthemi. Int. J. Syst. Bacteriol. 27:211-221.

4. Crosa, J. H., D. J. Brenner, W. H. Ewing, and S. Falkow. 1973. Molecular relationships among the salmonellae. J. Bacteriol. 115:307-315.

5. Crosa, J. H., A. G. Steigerwalt, G. R. Fanning, and D. J. Brenner. 1974. Polynucleotide sequence divergence in the genus Citrobacter. J. Gen. Microbiol. 83: 271-282.

6. De Ley, J., and R. Tijtgat. 1970. Evaluation of membrane filter methods for DNA-DNA hybridization. An tonie van Leeuwenhoek J. Microbiol. Serol. 36:461-474.

7. Ferragut, C., F. Gavini, D. Lzard, and $H$. Leclerc. 1978. Etude du \% GC dans un groupe d'entérobactéries $\mathrm{H}_{2} \mathrm{~S}^{-}$apparentées au genre Citrobacter. Can. J. Microbiol. 24:473-479.

8. Ferragut, C., and H. Leclerc. 1976. Etude comparative des méthodes de détermination du Tm de l'ADN bactérien. Ann. Microbiol. (Inst. Pasteur) 127A:223-235.

9. Ferragut, C., and H. Leclerc. 1978. Study of motile and negative acetoï Klebsiella pneumoniae strains. Antonie van Leeuwenhoek J. Microbiol. Serol. 44:407-424.

10. Gavini, F., C. Ferragut, D. Izard, P. A. Trinel, H. Leclerc, B. Lefebvre, and D. A. A. Mossel. 1979 Serratia fonticola, a new species from water. Int. J. Syst. Bacteriol. 29:92-101.

11. Gavini, F., C. Ferragut, and H. Leclerc. 1976. Etude taxonomique d'entérobactéries appartenant ou apparentées au genre Enterobacter. Ann. Microbiol. (Inst. Pasteur) 127B:317-335.

12. Gavini, F., H. Leclerc, B. Lefebvre, C. Ferragut, and D. Izard. 1977. Etude taxonomique d'entérobactéries appartenant ou apparentées au genre Klebsiella. Ann. Microbiol. (Inst. Pasteur) 128B:45-59.

13. Gavini, F., B. Lefebvre, and H. Leclerc. 1976. Positions taxonomiques d'entérobactéries $\mathrm{H}_{2} \mathrm{~S}^{-}$par rapport au genre Citrobacter. Ann. Microbiol. (Inst. Pasteur) 127A:275-295.

14. Gillis, M., J. De Ley, and M. De Cleene. 1970. The determination of molecular weight of bacterial genome DNA from renaturation. Eur. J. Biochem. 12:143-153.

15. Izard, D., C. Ferragut, F. Gavini, and H. Leclerc. 1978. Variations of the moles percent guanine plus cytosine within a group of Enterobacteriaceae belonging or related to the genus Enterobacter. Int. J. Syst. Bacteriol. 28:449-452.

16. Izard, D., F. Gavini, P. A. Trinel, and H. Leclerc. 1979. Rahnella aquatilis: un nouveau membre dans la famille des Enterobacteriaceae. Ann. Microbiol. (Inst. Pasteur) 130A:163-177.

17. Izard, D., F. Gavini, P. A. Trinel, and H. Leclerc. 1979. Etude d'un groupe nouveau d'Enterobacteriaceae (groupe $\mathrm{H}_{1}$ ) apparenté à l'espèce $E$. cloacae. Can. J. Microbiol. 25:713-718.

18. Legault-Demare, J., B. Desseaux, T. Heyman, S. Seror, and G. P. Ress. 1967. Studies on hybrid molecules of nucleic acids. I. DNA-DNA hybrids on nitrocellulose filters. Biochem. Biophys. Res. Comm. 28: $550-557$.

19. Mandel, M., and J. Marmur. 1968. Use of ultraviolet absorbance temperature profile for determining the 
guanine plus cytosine content of DNA. Methods Enzymol. 12B:195-206.

20. Marmur, J. 1961. A procedure for the isolation of deoxy ribonucleic acid from microorganisms. J. Mol. Biol. 3: 208-218.

21. Skerman, V. B. D., V. McGowan, and P. H. A. Sneath.
1980. Approved list of bacterial names. Int. J. Syst. Bacteriol. 30:225-420.

22. Steigerwalt, A. G., G. R. Fanning, M. A. Fife-Asbury, and D. J. Brenner. 1976. DNA relatedness among species of Enterobacter and Serratia. Can. J. Microbiol. 22:121-137. 